\title{
References:
}

1. Chystiak D.O., Mosenkis I.L. L'Intérieur et l'extérieur dans le premier théâtre de Maurice Maeterlinck. Studii si cercetari filologice. Seria Limbi Romanice. Pitesti, 2020. No. 27. P. 58-73.

2. Chystiak, D. Mythological poetic cosmology in the language of Ukrainian and Belgian symbolist poetry. Kyiv, Summit-Knyga, 2018. 684 p.

3. Chystiak D. Mythological poetic worldview in Belgian Symbolism. Kyiv, Raduga, 2016. 272 p.

DOI https://doi.org/10.30525/978-9934-26-073-5-1-75

\section{ЛІНГВОСТИЛІСТИЧНІ ТА ЕКОЛІНГВІСТИЧНІ ОСОБЛИВОСТІ ТВОРЧОСТІ ФЕНІМОРА КУПЕРА}

\author{
Чрділелі Т. В. \\ кандидат філологічних наук, доцент, \\ дочент кафедри перекладу \\ Кременчуиького національного університету \\ імені Михайла Остроградського \\ Якимець М. С. \\ аспірантка \\ Кременчуиького національного університету \\ імені Михайла Остроградського \\ м. Кременчук, Полтавська область, Україна
}

Показовою віхою розвитку сучасної лінгвістики $є$ не тільки ii антропоцентризм, але й поєднання наукових парадигм, тобто застосування теоретичних та методологічних засад суміжних дисциплін. Одним із таких нових напрямків є еколінгвістика, яка вводить ідеї гармонічного розвитку природи до мовознавчих студій. Як стверджує О. Іванова, ця наука поєднує екологію і лінгвістику, вона вивчає взаємодію між мовою, людиною та оточуючим середовищем, а мова при цьому розглядається як невід'ємний компонент ланцюга взаємовідносин між людиною, суспільством та природою [1, с. 2]. Виходячи із такого розуміння завдань еколінгвістики, можна вважати, що одним iз перспективних джерел досліджень у парадигмі цієї науки $є$ аналіз художніх текстів, які торкаються проблем взаємодії людини з оточуючим середовищем, навколишнім світом. Саме це визначило наш вибір на 
користь вивчення екологічної комунікації крізь призму романів Ф. Купера, ключовим концептом і темою яких $є$ відображення природи.

Френсіс Паркман, описуючи еколінгвістичничні аспекти творчості Джеймса Фенімора Купера зазначав: «Their virtue consists in their fidelity, in the strength with which they impress themselves on the mind, and the strange tenacity with which they cling to the memory. For our own part, it was many years since we had turned the pages of Cooper, but still we were haunted by the images which his spell had evoked» [2, c. 216].

Кожен читач, знайомий зі спадщиною Д. Ф. Купера, може підтвердити, що дане твердження правомірне чи не для будь-якого твору автора. У всіх без винятку романах пенталогії про Шкіряну Панчоху та інших творах присутні описи природи рідного краю, пронизані любов’ю автора до своєї країни.

Сучасники Купера відзначали, що в своїх творах він описував інші країни тільки для того щоб зробити наступний висновок: "Oh! This is much better in America».

Американський письменник не залишається байдужим до краси рідної землі і соціальним процесам того часу, що згодом знайшло своє найбільш яскраве відображення в життєвій позиції Натті Бампо.

3 перших рядків пенталогії про Соколине Око письменник розглядає природу як джерело первісної форми світу. Він знайомить читачів 3 місцевістю і подає ініціальний пейзаж або пейзаж-експозицію. Автор вважав, що невинність і чистота $\epsilon$ iі характерними рисами і вдало використав епітети, щоб подати контраст між природою і впливом людей на неї: «Broad belts of the virgin wilderness not only reached the shores of the first river, but they even crossed it, stretching away into New England, and affording forest covers to the noiseless moccasin of the native warrior, as he tread the secret and bloody war-path»[2, с. 2]. Людина, втомлена цивілізацією та постійними війнами в ній, шукає затишку в обіймах природи.

Купер спочатку задає загальний тон неоднозначності природи в цілому, яка супроводжує нас протягом усієї пенталогії, як своєрідну антиномію між словами virgin (невинний) i bloody (кривавий), оскільки ці лексичні одиниці в певному сенсі суперечать один одному, як і світ в якому живуть герої його творів.

Еколінгвістичні прийоми, застосовані автором дозволяють уявити собі всю велич природи Америки та поринути у світ письменника. Розвиток подій відбувається на початку червня, коли безхмарне небо та теплі дні сприяють подоланню перешкод, які встануть на шляху молодого героя: «balminess of June», «the calm of the June morning», 
«a glorious day in June». Сонячний пейзаж супроводжує героїв через весь роман, приковує їх увагу до багатства та різноманітності природи.

Для палітри автора характерні багатство кольорів, розкішна гра тонів і напівтонів, світла й тіні: «Ву this time the sun had not only risen, but it had appeared over the eastern mountains, and was shedding a flood of glorious light on this as yet unchristened sheet of water» [3, c. 125].

Сонце $є$ одним 3 головних компонентів природи в денних пейзажних описах письменниках. Як тільки перші проміні торкаються гладких поверхонь чи то озера, чи то промінь пробивається крізь гущавину лісу, все навколо оживає. Майстерне впровадження метафор, епітетів та поетичного вокабуляру розкривають перед читачем яскраві образи в його уяві.

Пейзажний опис набуває національного колориту завдяки золотистими та білими кольорами, які репрезентують епітети:«Тhe sun appeared above the tops of the pines, and the light of a golden American day streamed down into the valley, bathing «in deep joy» the lake, the forests and the mountain sides» [3, c. 459].

Словниковий запас автора багатий на поетичну лексику, яка гармонійно вписується в пейзажний опис місцевості. Благородні дуби та сосни, знаходячись під одним яскравим сонцем, проміння якого зігріває навіть самі недоступні частини дерев, ніби спілкуються одним з одним та насолоджуються безхмарним небом.

Пейзажні описи розкривають як семантичну домінанту всього тексту, так і домінуючі смисли його окремих частин. При створенні пейзажних характеристик Купер в своїх романах звертається до різних стилістичних засобів: епітетів, стилістичних порівнянь, метафор, персоніфікацій, стилістичних інверсій, градацій які, переплітаючись між собою, визначили його індивідуальний стиль.

Порівняння і метафора $є$ найважливішими засобами виразності при створенні вербального пейзажу Звіробоя; вони активізують внутрішні резерви мови, дозволяють по-новому зобразити знайомі всім природні об’єкти і явища, залучаючи добре відомі лексичні одиниці. Фенімор Купер акцентував увагу на необхідності гострої спостережливості i уважного проникнення в суть зображуваного за допомогою книжкової та поетичної лексики.

Для дієслівних одиниць, що займають значне місце в аналізованих пейзажних замальовках, характерно семантичне переосмислення, що приводить в більшості випадків до своєрідної персоніфікації описуваних природних явищ: Завдяки своєрідному вибору дієслівної лексики явища природи наділяються особливою активністю, виступають як мислячі 
діячі. Контекстуальна сполучуваність в такому випадку створює умови для прояву нових семантичних можливостей у даних дієслів.

В ході аналізу виявлено численні випадки контекстуальної антонімії і синонімії прикметників, використані для передачі різноманіття описуваного природного світу.

Аналіз стилістичного матеріалу творчості Ф.Купера показав, що виявлені стилістичні прийоми допомагають створити пронизливу атмосферу, передати почуття героїв, наділити природу людськими рисами, посилити образність мови, а використання колірних прикметників сприяє більш барвистому i розгорнутому опису природи в досліджуваному творі.

При виборі кольоративної лексики, автор концентрує увагу на різноманітності то світлих, то темних відтінків, що надає описам природи видимість, достовірність, створює емоційне забарвлення.

За типологією пейзажних описів в романах про Звіробоя можна дійти до висновків, що ідеальний пейзажний опис грає невід'ємну частину в романі, бо як і в будь-якого з романтиків, в автора ідеальне домінує над реальним, високе над буденним, поетичне над прозаїчним. Фенімор Купер використовує в творі великі пейзажні полотна, які допомагають підкреслити психологічний стан персонажів, причому динамічний пейзажний опис переважає над статичним. Природа описується Купером шляхом накопичення i неодноразового повторення окремих його деталей, що підкреслює основну рису пейзажного опису. Найвищий ступінь деталізації мають описи, де автор використовує сонячний пейзажний опис, щоб як найбільш точно зобразити кожну частинку Американського континенту.

Проведений аналіз підтверджує, що пенталогія Ф. Купера $\epsilon$ комплексним та багатогранним об'єктом дослідження, який уможливлює застосування еколінгвістичного підходу для отримання нових цікавих висновків про взаємодію мови, людини і природи.

\section{Література:}

1. Иванова Е.В. Цели, задачи и проблемы эколингвистики. Прагматический аспект коммуникативной лингвистики и стилистики. URL: http:// ecoliguistics.ru/index.php?sel=mat\&id=12

2. Parkman F. James Fenimore Cooper. Essays from the North American review; ed. by Allen Thorndike Rice. New York: D. Appleton and Company, 1879. 508 p. URL: https://archive.org/details/essaysfromnortha

3. The Deerslayer or the First War-Path. By J. Fenimore Cooper. New Edition. New York: Stringer and townsend. 1954. 544 p. 